\title{
The Thermal Activation of Nsu Clay for Enhanced Alumina Leaching Response
}

\section{Udochukwu Mark $^{1, a^{*}}$, Charles Nwachukwu Anyakwo ${ }^{1, b}$, Okechukwu Onyebuchi Onyemaobi ${ }^{1, \mathrm{c}}$ and Chijioke Samson Nwobodo ${ }^{1, \mathrm{~d}}$}

\author{
${ }^{1}$ Department of Materials and Metallurgical Engineering, \\ Federal University of Technology, Owerri, Nigeria \\ a*udochukwu.mark@futo.edu.ng, bcharlesanyakwo@yahoo.com, 'onyemaob@yahoo.com, \\ dcsnwobodo@yahoo.com
} Keywords: Nsu clay, Bauxite, kaolinite, alumina, calcination, thermal activation, leaching, activation
energy

\begin{abstract}
The thermal activation conditions for enhancing the leaching of alumina from Nsu clay from south-eastern Nigeria was investigated. The clay assayed $28.9 \% \mathrm{Al}_{2} \mathrm{O}_{3}$ and $50.59 \% \mathrm{SiO}_{2}$, comprising mainly kaolinite mineral $(82.6 \%)$ and quartz $(12.5 \%)$. Thermal activation rendered the alumina in the clay acid-soluble by transforming the clay from its crystalline nature to an amorphous phase or metakaolinite. The clay samples were heated at calcination temperatures of 500, 600, 700, 800 , and $900{ }^{\circ} \mathrm{C}$ at holding times of 30,60 , and 90 minutes. Uncalcined clay samples and samples calcined at $1000{ }^{\circ} \mathrm{C}$ (holding for 60 minutes) were used in the control experiments. Leaching of alumina from the resulting clay calcines passing $300 \mu \mathrm{m}$ sieve $(-50 \mathrm{mesh})$ was done in $1 \mathrm{M}$ hydrochloric acid solution at room temperature using a solid/liquid ratio of $0.02 \mathrm{~g} / \mathrm{ml}$ and shaking speed of $100 \mathrm{rpm}$. The solubility data given by the fraction of $\mathrm{Al}$ ion taken into leach solution showed that the clay calcined at $700{ }^{\circ} \mathrm{C}$ (holding for 60 minutes) responded most to leaching. In general, it was observed that samples calcined for 60 minutes responded better than those held for 30 or 90 minutes. The activation energies for leaching the clay calcines were 29.50, 32.92, 26.71, 30.18, 29.18, and $33.24 \mathrm{~kJ} / \mathrm{mol}$ for samples calcined for 60 minutes at 500, 600, 700, 800, 900, and $1000{ }^{\circ} \mathrm{C}$, respectively. The activation energy of leaching for the uncalcined sample was $35.07 \mathrm{~kJ} / \mathrm{mol}$. Thus, calcines produced at $700{ }^{\circ} \mathrm{C}$ (holding for 60 minutes) had the highest leaching response for alumina and the lowest leaching activation energy of $26.71 \mathrm{~kJ} / \mathrm{mol}$. It is concluded therefore that Nsu kaolinite clay should be best calcined for alumina yield by heating up to $700{ }^{\circ} \mathrm{C}$ and holding for 60 minutes at that temperature. The clay deposit can be used as alternative resource for alumina production.
\end{abstract}

\section{Introduction}

Primary aluminium is produced by the electrolytic reduction of alumina $\left(\mathrm{Al}_{2} \mathrm{O}_{3}\right)$ in the popular Hall-Héroult process [1] [2] [3] [4]. The alumina used is usually refined from bauxite, the traditional ore for aluminium [5] [6]. About 90 percent of the world production of bauxite is used for making alumina, most of which is consumed in the manufacture of aluminium. The rest is used in the production of abrasives, refractories, chemicals used chiefly in water purification and in the manufacture of paper, petroleum catalysts, aluminous cements, materials for the purification of kerosene and other petroleum products, and for other purposes [7] [8] [9] [10]. The West African subregion holds the largest bauxite resources in the world [11] [12] [13]. The U.S. Geological Survey put the world bauxite reserve at about 55 billion tonnes with West Africa having the highest share of $32 \%$ [10]. Countries in the sub-region (Nigeria's neighbours) hold about one-third of the world's bauxite reserves, and the resource is sold at locally unfavourable internationally competitive prices [10]. Bauxite deposits are found in Guinea, Sierra Leone, Ghana, Mali, Cameroon, and Gabon [11] [13] [15]. However, no economic deposits have been discovered in Nigeria [13] [16]. Only minor occurrences with low concentrations of bauxite minerals are reported from some regions like Ekiti province [17] [18] [19] and the Jos Plateau [11]. Again, only the occurrence of bauxitic clay is 
reported from the Mambilla Plateau (the western extension of the Adamawa Highland, near the border with Cameroon) [11] [13] [20]. This shows that the raw material for manufacture of alumina (i.e. bauxite) is very scarce in Nigeria.

The high-volume consumption of aluminium in Nigeria [14] [16] and the establishment of an aluminium smelter plant at Ikot-Abasi [16] [21] puts pressure on the country to develop methods for producing alumina from nonbauxite alumina/aluminium bearing raw materials. The kaolinitic clays are aluminous raw materials and are well distributed on a large scale in Nigeria [12] [13] [20] [22].

Kaolinite clay has the structural formula in which the silica tetrahedral layer, represented by $\left(\mathrm{Si}_{2} \mathrm{O}_{5}\right)^{2-}$ is made electrically neutral by an adjacent aluminium octahedral layer, $\mathrm{Al}_{2}(\mathrm{OH})_{4}{ }^{2+}[23]$ [24]. Taking one silicon tetrahedral unit and one aluminium octahedral unit, the structural formula of kaolinite can be written as $\mathrm{Al}_{2}(\mathrm{OH})_{4} \cdot\left(\mathrm{Si}_{2} \mathrm{O}_{5}\right)$ or $\mathrm{Al}_{2} \mathrm{Si}_{2} \mathrm{O}_{5}(\mathrm{OH})_{4}$ or in terms of oxides as $\mathrm{Al}_{2} \mathrm{O}_{3} \cdot 2 \mathrm{SiO}_{2} \cdot 2 \mathrm{H}_{2} \mathrm{O}$. In its pure form, kaolinite has the theoretical composition of $46.54 \% \mathrm{SiO}_{2}$, $39.50 \% \mathrm{Al}_{2} \mathrm{O}_{3}$, and $13.96 \% \mathrm{H}_{2} \mathrm{O}$ (equivalent to loss on ignition or LOI). This makes kaolinite the clay mineral with the highest content of alumina [25] [26]. Kaolinite clays are therefore potential sources of alumina where bauxite is scarce or depleted. In view of Nigeria's situation, the abundant reserve of kaolinitic clays is thought as a suitable substitute for bauxite from which alumina of high purity can be obtained [27].

\begin{tabular}{|c|c|c|c|}
\hline $\begin{array}{c}\text { Reversible Transformation } \\
\text { Normal Clay } \\
\text { Structure } \\
\text { (Crystalline) }\end{array}$ & $\begin{array}{c}\text { Anhydrous } \\
\text { Clay Structure } \\
\text { (Crystalline) }\end{array}$ & $\begin{array}{c}\text { Irreversible Transformation } \\
\text { Anhydrous } \\
\text { Clay Structure } \\
\text { (Amorphous) }\end{array}$ & $\begin{array}{c}\text { Anhydrous } \\
\text { Recrystallized } \\
\text { Structure }\end{array}$ \\
\hline$\leq \mathbf{1 2 0}^{\circ} \mathbf{C}$ & $120-550^{\circ} \mathrm{C}$ & $550-900^{\circ} \mathrm{C}$ & $\geq 900^{\circ} \mathrm{C}$ \\
\hline & Heating (Increasing Temperature) $\rightarrow$ \\
\hline & $\leftarrow$ Cooling (Decreasing Temperature) \\
\hline
\end{tabular}

Figure 1. Effect of temperature on the physical state of clay minerals

However, the alumina content of kaolinite (and other clay minerals) is locked up in the clay structure. It can only be rendered leachable after proper thermal treatment known as activation [28]. As illustrated in Figure 1, four temperature ranges are important in the transformation of clays [29], namely: the drying range or free-water dehydration range $\left(50-120^{\circ} \mathrm{C}\right)$; the clay stability range $(120$ $\left.600{ }^{\circ} \mathrm{C}\right)$; the anhydrous clay range $\left(600-900^{\circ} \mathrm{C}\right.$ ); and the recrystallization range (above $900^{\circ} \mathrm{C}$ ). For example, kaolinite is reported to change from hydroplastic condition to leather hard, then stone hard and finally to anhydrous condition or metakaolinite as it is heated between room temperature and about $600{ }^{\circ} \mathrm{C}$ [30] [31]. This is because of drying, dehydration and dihydroxylation, as follows:

i.Drying or loss of wetness or physically adsorbed water by evaporation occurs at temperatures below $120^{\circ} \mathrm{C}$. The loss of physically attached water is endothermic and results in measurable weight loss. For kaolinite, the weight loss is usually minor, and the changes due to loss of physical water do not alter the crystalline structure of the clay [30]. Within the drying range, liquid water is removed from the clay, and the resulting material is referred to as leather dry or leather hard clay [31].

ii.Dehydration is further loss of any remaining physically held water between $120^{\circ} \mathrm{C}$ and about 550 ${ }^{\circ} \mathrm{C}$. The resulting material after this transformation is referred to as bone-dry or stone hard clay. Throughout the drying and dehydration temperature range (where physical water is removed), the expulsion of water is reversible as shown in Figure 1[29] [31].

iii.De-hydroxylation is loss of constitutional or chemically combined water (the $\mathrm{OH}$ water). Around $550{ }^{\circ} \mathrm{C}$, the chemically combined water in clays begins to be released. This transformation continues until all chemically combined water is expelled resulting in the formation of metakaolin, an anhydrous form of kaolin. As with the loss of physically adsorbed water, the loss of the chemically combined water is an endothermic process that is accompanied by weight loss. The magnitude of the weight loss depends on the amount of chemically combined water in the clay. After de-hydroxylation, metakaolin appears amorphous on X-ray diffraction, but the 
short-range ordering of the cations within the sheets that make up the kaolinite structure is retained. Metakaolin is a homogeneous molecular-level mixture of non-crystalline alumina and silica and does not spontaneously rehydrate when it is exposed to water and it remains stable up to approximately $980^{\circ} \mathrm{C}[30]$ [31].

The thermal changes of kaolinite heated above $600{ }^{\circ} \mathrm{C}$ can be outlined in accordance with the following sequence of reactions [28] [32]:

$$
\begin{aligned}
& \underbrace{\mathrm{Al}_{2} \mathrm{O}_{3} \cdot 2 \mathrm{SiO}_{2} \cdot 2 \mathrm{H}_{2} \mathrm{O}}_{\text {Kaolin }} \underset{\begin{array}{c}
\text { Dehydration } \\
\text { above } 600^{\circ} \mathrm{C}
\end{array}}{\mathrm{Al}_{2} \mathrm{O}_{3} \cdot 2 \mathrm{SiO}_{2}}+\underbrace{2 \mathrm{H}_{2} \mathrm{O}}_{\begin{array}{c}
\text { Metakaolin } \\
\text { Watitutional }
\end{array}} \\
& \underbrace{4\left(\mathrm{Al}_{2} \mathrm{O}_{3} \cdot 2 \mathrm{SiO}_{2}\right)}_{\text {Metakaolin }} \underset{950-980^{\circ} \mathrm{C}}{\longrightarrow} \underbrace{3 \mathrm{Al}_{2} \mathrm{O}_{3} \cdot 2 \mathrm{SiO}_{2}}_{\text {Primary Mullite }}+\underbrace{\gamma-\mathrm{Al}_{2} \mathrm{O}_{3}}_{\begin{array}{c}
\text { Gamma-Alumina } \\
\text { (fcc) }
\end{array}}+\underset{\begin{array}{c}
\text { Amorphous } \\
\text { Silica }
\end{array}}{6 \mathrm{SiO}_{2}} \\
& \underbrace{\gamma-3 \mathrm{Al}_{2} \mathrm{O}_{3}}_{\begin{array}{c}
\text { Gamma-Alumina } \\
\text { (fcc) }
\end{array}}+\underset{\begin{array}{c}
\text { Amorphous } \\
\text { Silica }
\end{array}}{3 \mathrm{SiO}_{2}} \stackrel{1,000-1,400^{\circ} \mathrm{C}}{\longrightarrow} \underbrace{3 \mathrm{Al}_{2} \mathrm{O}_{3} \cdot 2 \mathrm{SiO}_{2}}_{\text {Secondary Mullite }}+\underbrace{\mathrm{SiO}_{2}}_{\text {Tridymite }} \\
& \underbrace{3 \mathrm{Al}_{2} \mathrm{O}_{3} \cdot 2 \mathrm{SiO}_{2}}_{\text {Secondary Mullite }}+\underbrace{\mathrm{SiO}_{2}}_{\text {Tridymite }} \underset{1,400-1,580^{\circ} \mathrm{C}}{\longrightarrow} \underbrace{3 \mathrm{Al}_{2} \mathrm{O}_{3} \cdot 2 \mathrm{SiO}_{2}}_{\text {Mullite }}+\underbrace{\mathrm{SiO}_{2}}_{\text {Cristobalite }}
\end{aligned}
$$

Thus, the thermal changes of kaolinite heated above $600{ }^{\circ} \mathrm{C}$ progress in four major steps, namely: endothermic dehydration by de-hydroxylation of kaolinite $\left(\mathrm{Al}_{2} \mathrm{O}_{3} \cdot 2 \mathrm{SiO}_{2} \cdot 2 \mathrm{H}_{2} \mathrm{O}\right)$ to metakaolinite $\left(\mathrm{Al}_{2} \mathrm{O}_{3} \cdot 2 \mathrm{SiO}_{2}\right)$; sudden exothermic crystallization at about $980^{\circ} \mathrm{C}$ resulting to the formation of primary mullite $\left(3 \mathrm{Al}_{2} \mathrm{O}_{3} \cdot 2 \mathrm{SiO}_{2}\right), \gamma$-alumina and amorphous silica; further recrystallization to secondary mullite and tridymite; and then transformation of tridymite to cristobalite. Whereas reaction (1) or the first transformation is associated with loss in weight (due to LOI); all four transformations are accompanied by considerable volume and enthalpy changes [28].

The temperatures at which these transformations (phase changes) begin and end depends on (i) degree of crystallinity of the kaolinite, (ii) its impurity oxides contents, (iii) particle sizes, rate of heating, and duration of heating at a given temperature. Therefore, clays from different localities vary considerably not just in mineralogy and chemical composition, but in degree of crystallinity and purity [28] [33]. There is need to investigate the peculiar characteristics of each clay deposit. The current investigation is focused therefore on determining the thermal treatment required to transform Nsu clay found in south-eastern Nigeria to an anhydrous amorphous phase or metakaolinite. The response of the clay calcines to alumina leaching in hydrochloric acid solution vis-à-vis the thermal treatments was also studied.

\section{Materials and Methods}

Raw clay sample obtained from Nsu clay deposit (Lat. 5³7'24" N, Long. $7^{\circ} 18^{\prime} 52^{\prime \prime}$ E) in Ehime Mbano Council of Imo state, Nigeria was sun-dried, crushed and ground. The ground clay sample was placed on a $300 \mu \mathrm{m}$ ASTM sieve and shaken for 5 minutes. The oversize was further ground and sieved on the same sieve. The procedure was repeated until the entire clay sample passed through the $300 \mu \mathrm{m}$ sieve ( 50 standard Tyler mesh).

\subsection{Mineralogical and chemical analyses}

Representative sample of the sieved clay was analysed using Pananalytical XRD (Empyrean model) to determine the constituent minerals. Optimally calcined sample of the clay was also analysed with XRD to determine the effect of thermal transformation on the clay. Similarly, the chemical composition (amounts of $\mathrm{Al}_{2} \mathrm{O}_{3}, \mathrm{SiO}_{2}, \mathrm{TiO}_{2}$, etc.) was determined by means of Buckscientific AAS (model 210 VGP).

\subsection{Calcination procedures}

Ground and sieved clay samples passing $300 \mu \mathrm{m}$ sieve were subjected to thermal treatments in a muffle furnace at a heating rate of $15^{\circ} \mathrm{C}$ per minute up to the holding temperature $(500,600,700$, 
800 or $900^{\circ} \mathrm{C}$ ) and held for 30,60 or 90 minutes before furnace-cooling to room temperature. In addition, two sets of thermal treatment were used for the control experiment. A sample of the clay was reserved in the uncalcined condition (room temperature) and used as control 1; while another sample was heated up to $1000{ }^{\circ} \mathrm{C}$ and held for 60 minutes and used as control 2 .

\subsection{Leaching of clay calcines}

Analytical grade $\mathrm{HCl}$ acid and pure deionized water were used to prepare the leaching reagent. 1 molar standard solution of hydrochloric acid was prepared using deionized water. This was used as the leaching reagent for the leaching studies to determine the leaching response of the various clay calcines and the controls. The leaching was done under moderate leaching conditions, i.e. hydrochloric acid concentration of $1 \mathrm{M}$, leaching temperature at ambient $\left(\sim 25^{\circ} \mathrm{C}\right)$, shaking speed of $100 \mathrm{rpm}$, and solid/liquid ratio or clay weight to acid volume ratio of $0.02 \mathrm{~g} / \mathrm{ml}$, using clay particles passing $300 \mu \mathrm{m}(-50 \mathrm{mesh})$.

The leach contact time or duration ranged from 0 to 120 minutes at intervals of 30 minutes. The flask or reaction bottle was shaken at a constant rate of $100 \mathrm{rpm}$ during the contact time (duration of leaching) to facilitate the reaction. This was achieved by means of a KOMA orbital shaker (model KED11). By the end of leaching, the resulting slurry was filtered to separate undissolved materials (residue) from the filtrate (leachate or pregnant solution). The leachate was analysed for aluminium ion concentration.

This procedure was repeated for all the clay calcines and the control samples, which were prepared at different temperatures and duration of calcination. The optimum condition for calcining the clay was determined using solubility data (concentration and fraction of aluminium ion solubilized).

After examination of the extent of aluminium extraction or solubilization from the clay calcines, the calcine with the best leaching response for each calcination temperature was subjected to activation energy studies to establish the thermodynamic basis for their better leaching kinetics. This was in accordance with the Arrhenius rate law, viz:

$$
k=A e^{-\left(\frac{E_{a}}{R T}\right)} \quad \text { or } \quad \ln k=-\left(\frac{\mathrm{E}_{\mathrm{a}}}{\mathrm{R}}\right) \cdot \frac{1}{\mathrm{~T}}+\ln A
$$

where, $k$ is the leaching rate constant, $A$ is the Arrhenius frequency factor, $E_{a}$ is the activation energy for the leaching reaction, $R$ is the universal gas constant $\left(=8.314 \mathrm{~J} \cdot \mathrm{mol}^{-1} \cdot \mathrm{K}^{-1}\right)$, and $\mathrm{T}$ is the leaching temperature on the absolute scale.

Thus, samples held for 60 minutes at different temperatures of calcination were leached in $1 \mathrm{M}$ $\mathrm{HCl}$ at $25,50,75$ and $100{ }^{\circ} \mathrm{C}$ for a reaction contact time of 60 minutes. All other variables such as clay particle size, shaking speed, and solid/liquid ratio were kept constant at less than $300 \mu \mathrm{m}(-50$ mesh), $100 \mathrm{rpm}$ and $0.02 \mathrm{~g} / \mathrm{ml}$, respectively. The natural logarithm of rate constants $(\ln k)$ as deduced from the solubility data (based on second-order reaction kinetics which appeared to fit the data) and the reciprocal of absolute temperature $\left(\frac{1}{\mathrm{~T}}\right)$ were used for Arrhenius plots to determine the activation energy $\left(E_{a}\right)$ in the case of each clay calcine [34].

\section{Results and Discussion}

\subsection{Type and composition of clay}

Nsu clay is dominated by kaolinite mineral $(82.6 \%)$ followed by quartz or free silica $(12.5 \%)$, and traces of other impurities (Table 1). The chemical composition shows that the clay contains $50.59 \%$ silica, $28.9 \%$ alumina, loss on ignition (LOI) of $12.7 \%$ while impurity or accessory oxides make-up the balance of $7.81 \%$ (Table 1). The alumina content of $28.9 \%$ is considered good enough for hydrometallurgical treatment of the clay as a source of alumina [6] [35] [36].

The x-ray diffraction pattern of the raw clay is shown in Figure 2 in which peaks for the constituent mineral phases are clearly identified. Similarly, Figure 3 is the XRD pattern for the optimal clay calcine showing that the sharp kaolinite peaks in Figure 2 are no longer distinct. The 
disappearance of the kaolinite peaks is indicative of the appearance of an amorphous phase (metakaolinite) due to thermal transformation of the clay. A study of the phase transformations of kaolinite from different deposits in Russia and Ukraine showed similar results [33]. It is this amorphous metakaolinite $\left(\mathrm{Al}_{2} \mathrm{O}_{3} \cdot 2 \mathrm{SiO}_{2}\right)$ that releases alumina $\left(\mathrm{Al}_{2} \mathrm{O}_{3}\right)$ for dissolution making the clay respond to acid leaching. Thus, proper thermal treatment and transformation of the clay activates it for acid leaching [28].

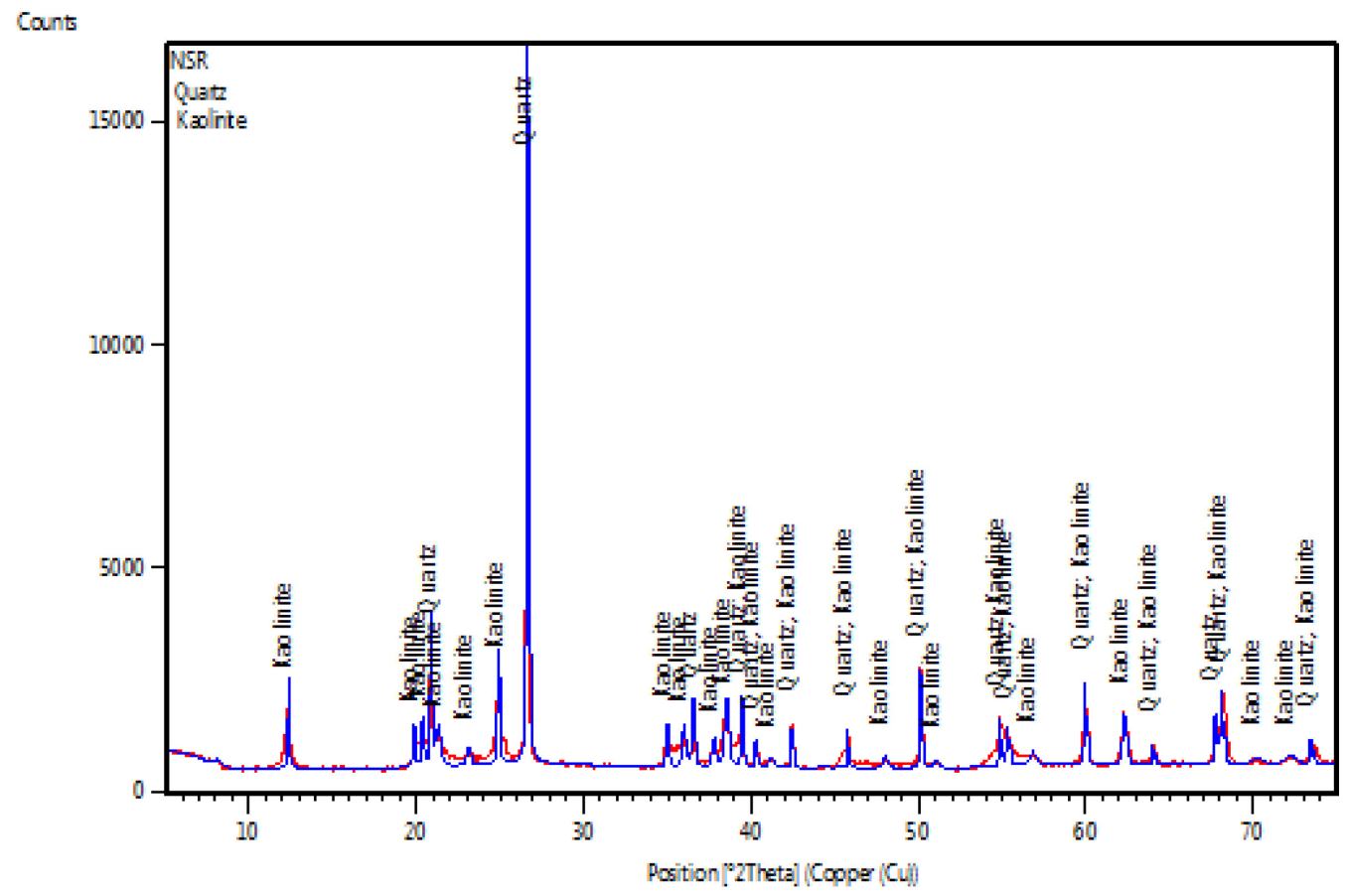

Figure 2. XRD pattern (diffractogram) of uncalcined Nsu clay

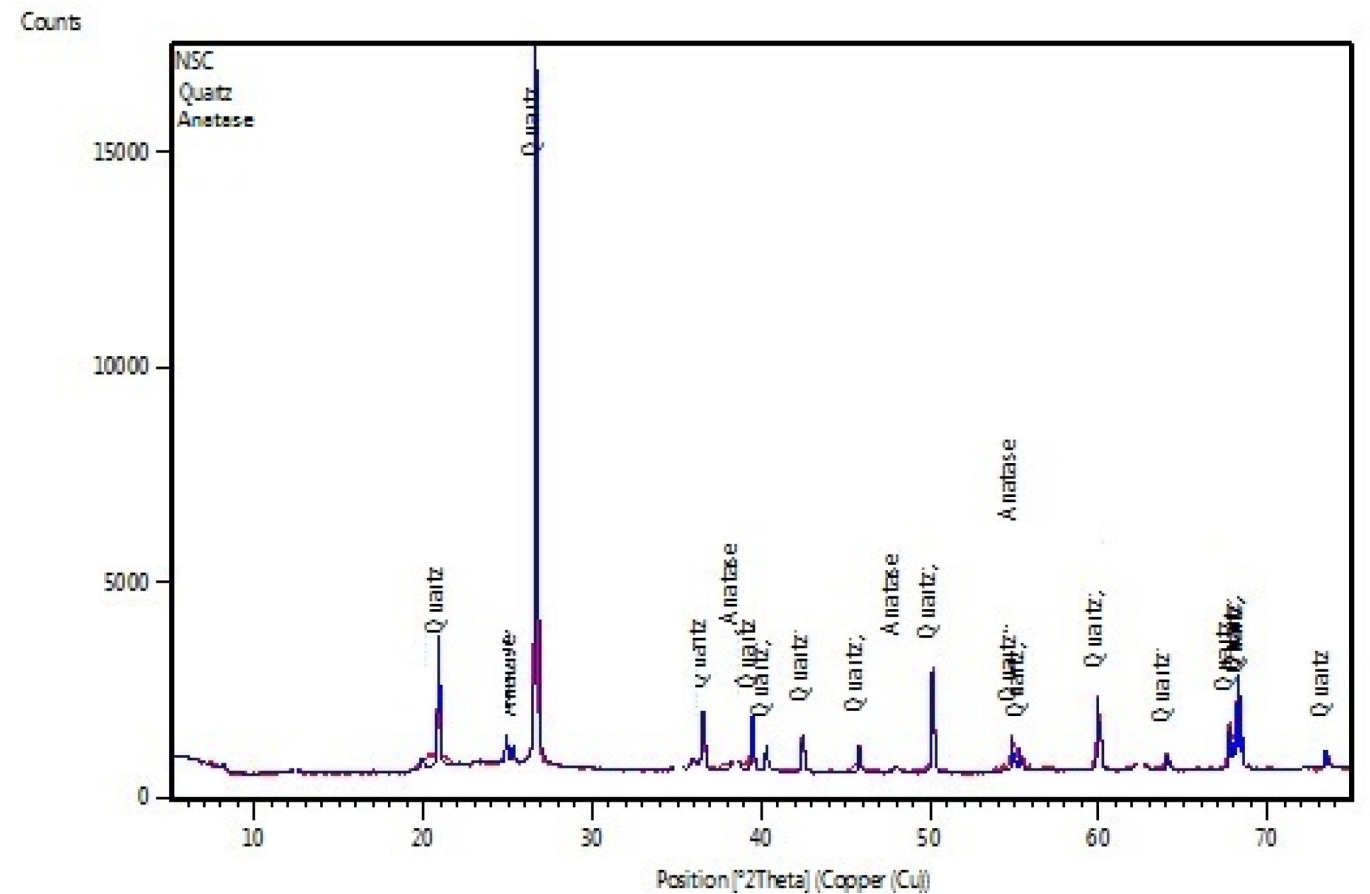

Figure 3. XRD pattern of Nsu clay calcined at $700{ }^{\circ} \mathrm{C}$ for 1 hour 
Table 1. Mineralogical and Chemical Analyses of Nsu Clay

\begin{tabular}{|c|c|c|c|}
\hline \multicolumn{2}{|c|}{ Mineral Constituents (\%) } & \multicolumn{2}{|c|}{ Chemical Composition $(\%)$} \\
\hline Kaolinite & $\mathbf{8 2 . 6}$ & $\mathrm{SiO}_{2}$ & 50.59 \\
\hline Quartz & 12.5 & $\mathrm{Al}_{2} \mathbf{O}_{3}$ & $\mathbf{2 8 . 9}$ \\
\hline Others & 4.9 & $\mathrm{Fe}_{2} \mathrm{O}_{3}$ & 1.34 \\
\hline & & $\mathrm{TiO}_{2}$ & $\mathbf{0 . 6 5}$ \\
\hline & & $\mathrm{CaO}$ & 0.53 \\
\hline & & $\mathrm{MgO}$ & 0.86 \\
\hline & & $\mathrm{Na}_{2} \mathrm{O}$ & 0.34 \\
\hline & & $\mathrm{K}_{2} \mathrm{O}$ & 0.42 \\
\hline & & $\mathrm{LOI}$ & 12.7 \\
\hline
\end{tabular}

\subsection{Response to acid leaching}

The dissolution of alumina from the clay was measured by the concentration of $\mathrm{Al}$ ions detected in leach solutions after leaching the various clay calcines. This was expressed in percentage or as a fraction. The fraction of $\mathrm{Al}$ ions $\left(X_{A l}\right)$ leached out of the clay into the solution was given as $\mathrm{X}_{\mathrm{Al}}=$ $\frac{\text { concentration of } \mathrm{Al} \text { ions in the solution }}{\text { concentration of } \mathrm{Al} \text { ions in the original clay sample }}$ while the percent $\mathrm{Al}$ ions $(\% \mathrm{Al})$ leached out of the clay into the solution was expressed as $\% \mathrm{Al}=100 \cdot \mathrm{X}_{\mathrm{Al}}$. The results showed that thermal treatment has significant effect on the amount of $\mathrm{Al}$ ions taken into solution. The effect of calcination temperatures at different durations of heating (30, 60 or 90 minutes) is illustrated in Figures 4, 5 and 6.

It was observed that response to leaching is lowest for the uncalcined clay sample (control $1, \sim 25{ }^{\circ} \mathrm{C}$ ) followed by that calcined at $1000{ }^{\circ} \mathrm{C}$ (control 2). The ability of the acid $(1 \mathrm{M} \mathrm{HCl})$ to extract alumina from the clay (and enrich the leach solution with aluminium ions) varied as calcination temperature increased from 500 to $900{ }^{\circ} \mathrm{C}$. However, at $1000{ }^{\circ} \mathrm{C}$ (control 2), the ability of the acid to attack the clay and remove alumina dropped drastically. Under 30, 60 and 90 minutes holding times (Figures 4, 5 and 6); the peak leaching response occurred in the case of samples calcined at $700{ }^{\circ} \mathrm{C}$. As shown, between 500 and $900{ }^{\circ} \mathrm{C}$; the response of Nsu clay to leaching by acid attack increased and dropped, reaching its peak at $700{ }^{\circ} \mathrm{C}$. This behaviour is probably due to the transformation of the clay from its room temperature crystalline form (kaolinitic) to various degrees of amorphous state (metakaolinitic) and back to high temperature crystalline form at $1000{ }^{\circ} \mathrm{C}$ and beyond, as the clay steadily lost physically combined water (through drying and dehydration) and chemically combined water (dehydroxylation) as temperature increased. It means therefore that the clay transformed completely to an amorphous phase (metakaolinite) when it was heated to $700{ }^{\circ} \mathrm{C}$, while crystallinity or various degrees of crystallinity existed in the clay below and above $700{ }^{\circ} \mathrm{C}$. 


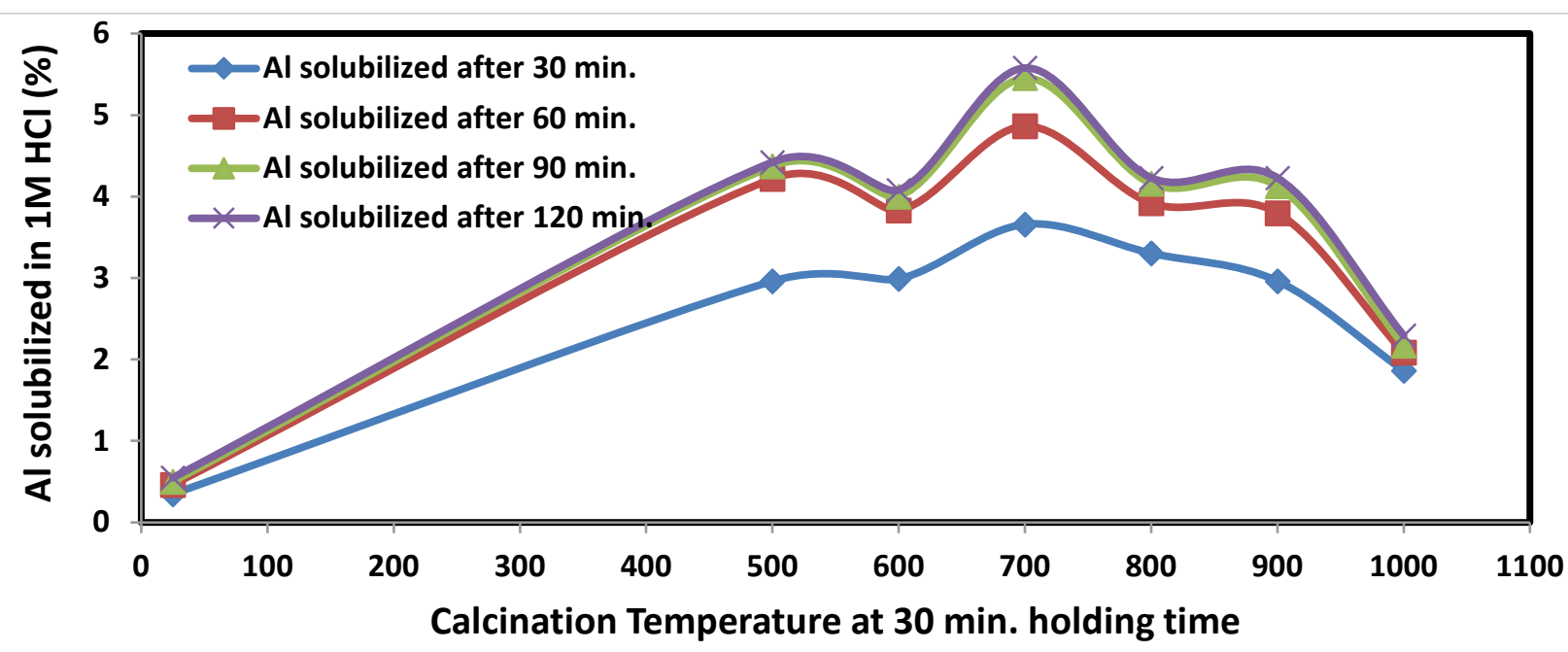

Figure 4. Effect of calcination temperature at 30 minutes holding time on the solubilization of $\mathrm{Al}$ from Nsu clay leached at room temperature

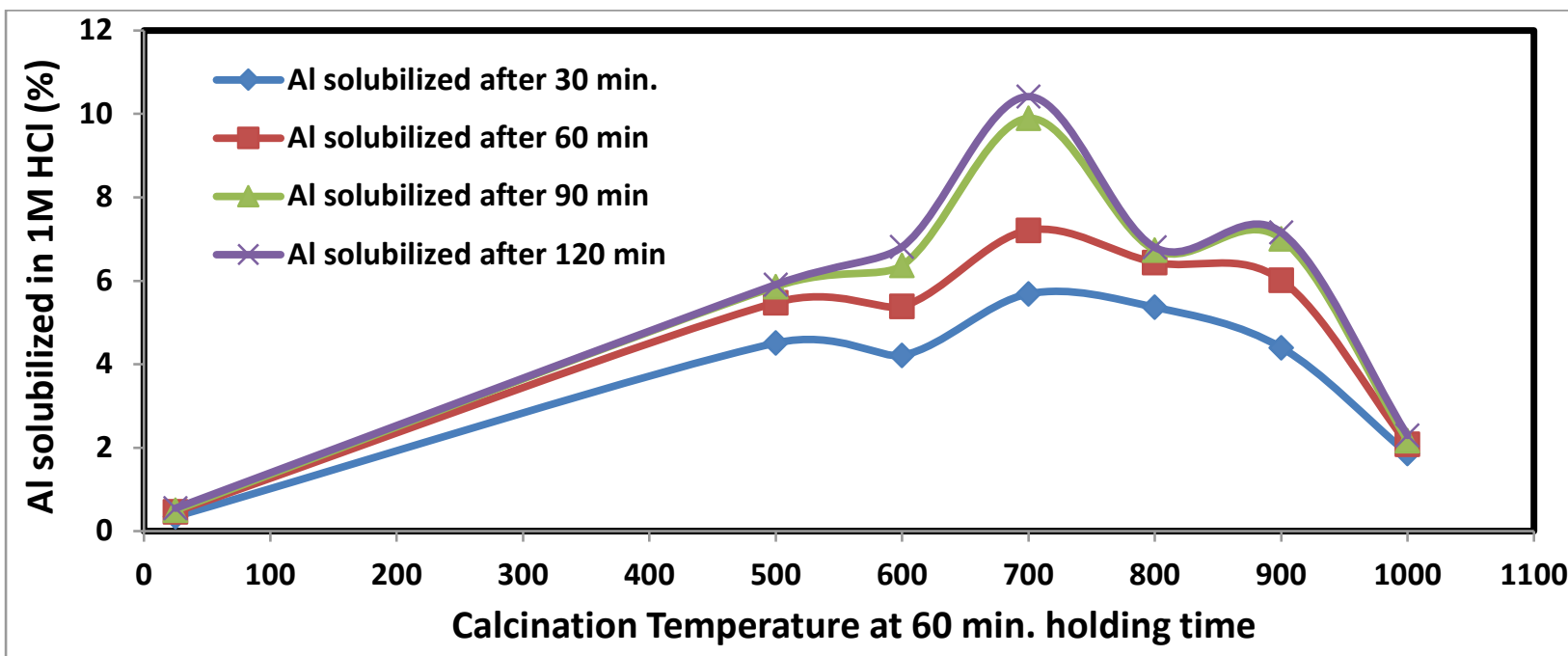

Figure 5. Effect of calcination temperature at 60 minutes holding time on the solubilization of $\mathrm{Al}$ from Nsu clay leached at room temperature

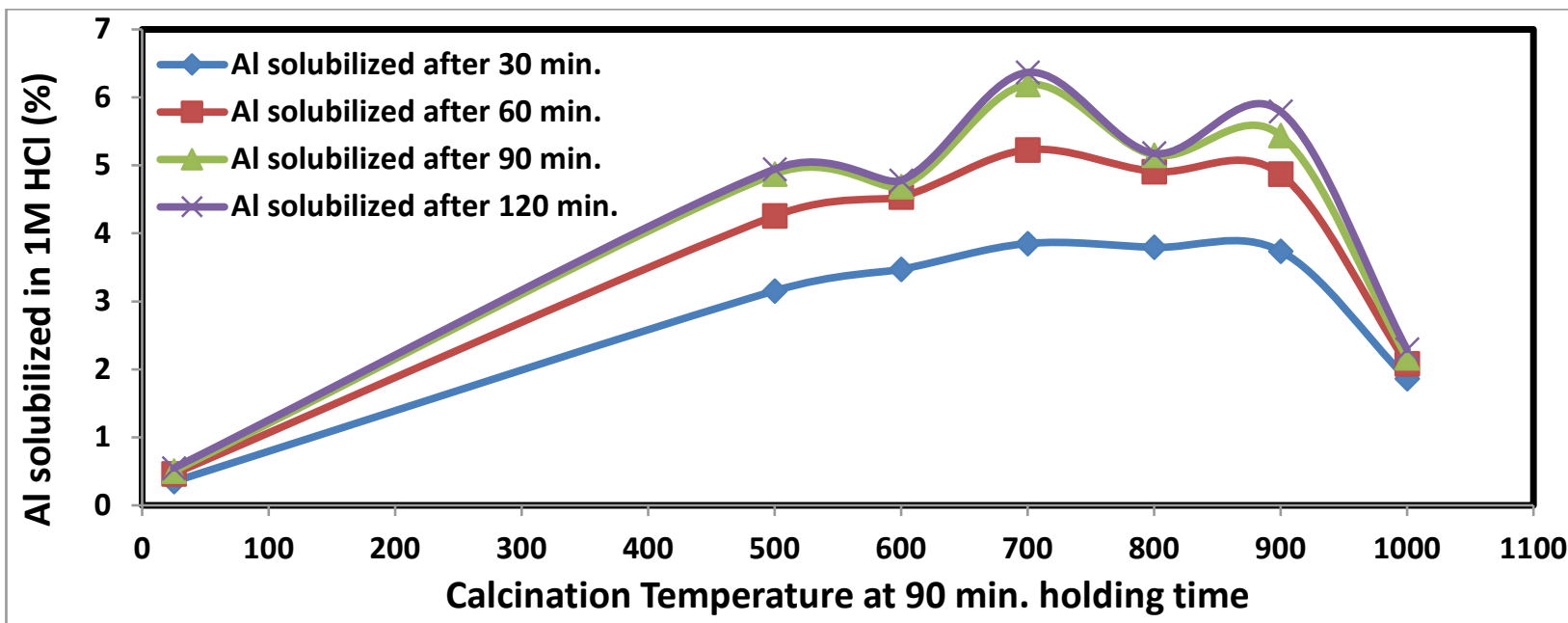

Figure 6. Effect of calcination temperature at 90 minutes holding time on the solubilization of $\mathrm{Al}$ from Nsu clay leached at room temperature 


\subsection{Effect of holding time}

Another interesting observation is that samples held for 60 minutes in the furnace responded better on leaching than those held for 30 or 90 minutes at all calcination temperatures investigated (Figure 7). For example, after 120 minutes of leaching in $1 \mathrm{M} \mathrm{HCl}$, the percent $\mathrm{Al}$ extracted in the case of samples calcined at $700{ }^{\circ} \mathrm{C}$ were $5.58,10.41$, and $6.37 \%$ respectively for holding times of 30 , 60 , and 90 minutes. This means that the ability of the acid to attack alumina in the clay and remove aluminium was low at 30 minutes holding time, reached peak value at 60 minutes holding time, and declined again when holding time was extended to 90 minutes at all temperatures studied $(500,600$, 700,800 , and $900{ }^{\circ} \mathrm{C}$ ). This observation could be because at 30 minutes, the transformation of the clay to amorphous (non-crystalline) state was just beginning, the transformation to amorphous metakaolinite reached advanced stage after 60 minutes, but holding up to 90 minutes resulted to the reappearance of some crystallinity. Prolonged heating can therefore make the silica and alumina contents of clay to react, resulting in reduction of solubility. Furthermore, prolonged heating may also bring about the sintering of particles or phases leading to reduction in leaching response [37]. It can be concluded therefore that 60 minutes or 1 hour is the optimum calcination holding time for thermally activating Nsu clay to respond maximally to leaching in acid.

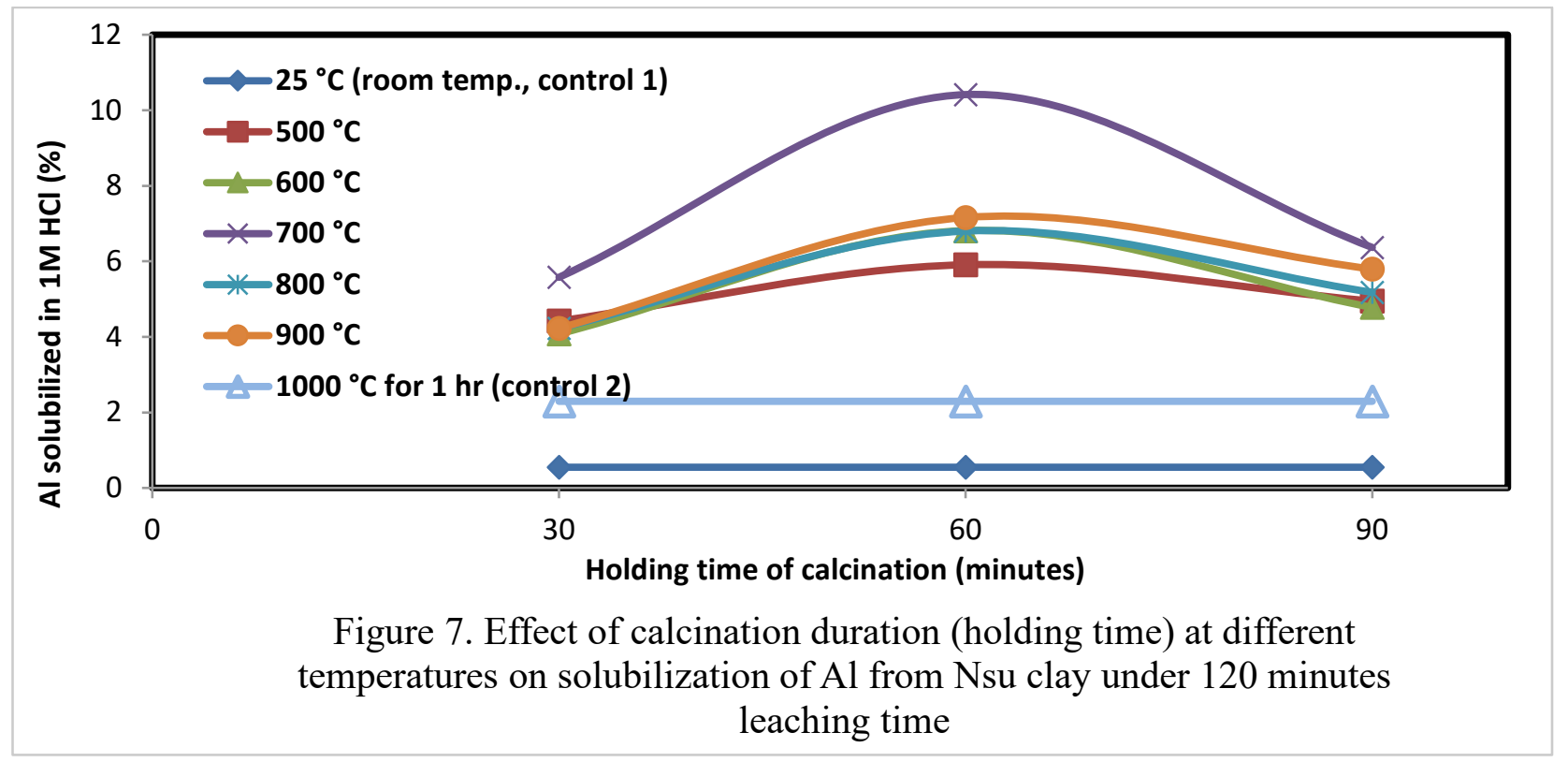

These observations are in agreement with XRD patterns shown in Figures 2 and 3 for the raw and optimally calcined clays. Thermal treatment therefore broke down the clay structure by removing the $\mathrm{OH}$ water (chemically combined) holding the network of silica tetrahedra and alumina octahedra, thus rendering the alumina acid-soluble. At sufficiently high temperatures or for prolonged heating durations, the silica and alumina recrystallized to form a crystalline and insoluble phase (e.g. mullite). It can be concluded therefore that heating to $700{ }^{\circ} \mathrm{C}$ and holding for 60 minutes is the optimum calcination temperature and duration for thermally activating Nsu clay to respond optimally to acid leaching.

\subsection{Effect of leaching temperature and thermal activation}

As noted earlier, clay calcines produced by holding for 60 minutes in the furnace (at all calcination temperatures studied) responded to leaching better than those held for 30 or 90 minutes. The effect of leaching temperature on the leaching response of calcines produced under 60 minutes duration of calcination was studied further; the result is given in Figure 8. As shown, at all calcination temperatures investigated, leaching response increased as leaching temperature increased. In the case of the optimal calcine $\left(700{ }^{\circ} \mathrm{C}\right.$ held for 60 minutes), the amounts of aluminium solubilised after leach contact time of 1 hour in $1 \mathrm{M} \mathrm{HCl}$ were $11.22,21.25,36.50$, and $52.26 \%$ for leaching temperatures of 
$25,50,75$, and $100{ }^{\circ} \mathrm{C}$, respectively. It can be concluded that leaching temperature has a significant effect on the rate of alumina dissolution from the clay. This is because high temperatures enhance diffusion or mobility and hence collision frequency of reacting species in addition to providing extra thermal energy for overcoming the energy barrier or activation energy for the process. These observations have been corroborated by other researchers [38] [39] [40].

The effect of thermal activation on leaching of clay calcines at different leaching temperatures is also shown in Figure 8. For example, the amount of $\mathrm{Al}$ extracted within 1 hour of leaching in $1 \mathrm{M}$ $\mathrm{HCl}$ at $100{ }^{\circ} \mathrm{C}$ increased from $7.12 \%$ to $52.26 \%$ over the activation temperature range $25{ }^{\circ} \mathrm{C}$ (for uncalcined clay) to $700{ }^{\circ} \mathrm{C}$ (optimal calcine). Then there was a steady decline in $\mathrm{Al}$ extraction to $24.02 \%$ (for calcine produced at $1000^{\circ} \mathrm{C}$ ). Similar trends were also observed at leaching temperatures of 25,50 and $75^{\circ} \mathrm{C}$. This can be explained based on solid phase changes or transformations in the clay brought about by thermal treatment [37] [38] [39] [40].

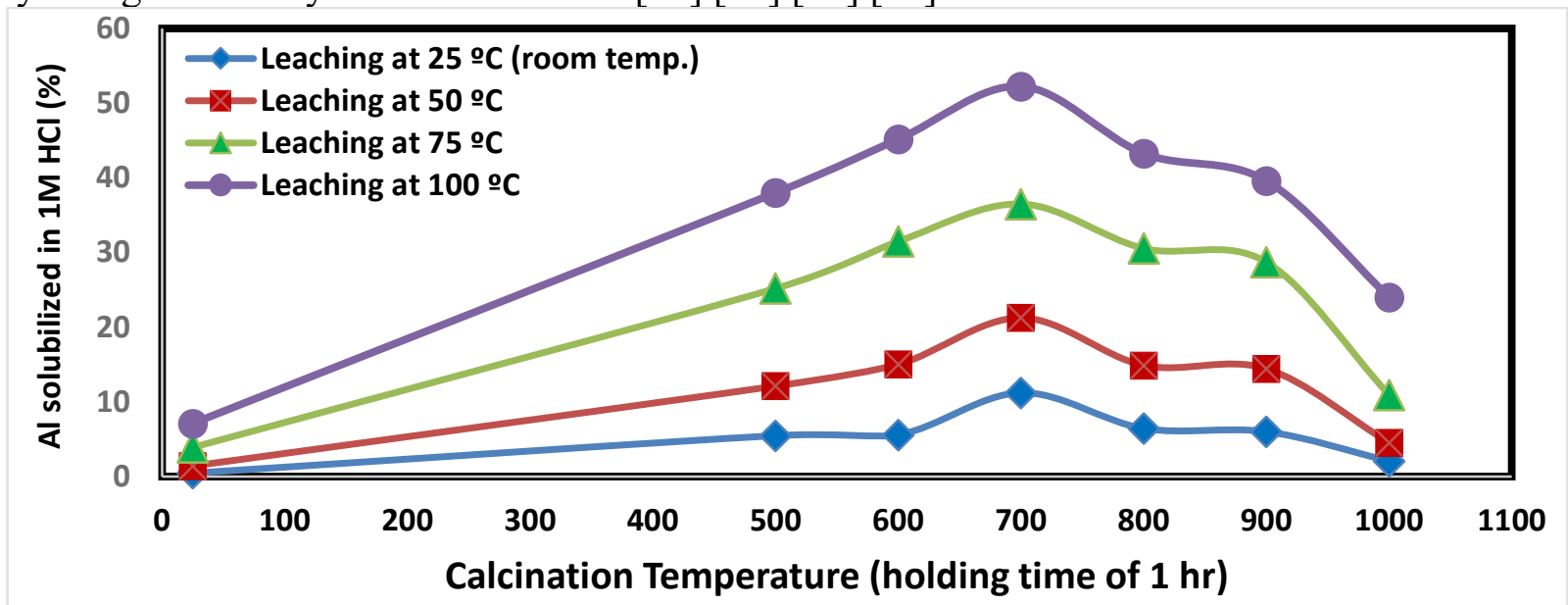

Figure 8. Effect of leaching temperature on the leaching response of selected Nsu clay calcines within leach contact time of 60 minutes

\subsection{Effect of thermal treatment on activation energy}

The activation energy of leaching was found to depend on the thermal treatment given to the clay. Low activation energies were obtained in the case of the clay calcines that responded well to leaching i.e. those with high level of Al extraction. This shows that the optimal calcination temperature and duration corresponded with the lowest activation energy (Table 2). Figure 9 shows plots of $\ln k$ versus $1 / \mathrm{T}$ for samples calcined under 60 minutes holding time and leached at different temperatures, i.e. $25{ }^{\circ} \mathrm{C}(298 \mathrm{~K}), 50{ }^{\circ} \mathrm{C}(323 \mathrm{~K}), 75{ }^{\circ} \mathrm{C}(348 \mathrm{~K})$ and $100{ }^{\circ} \mathrm{C}(373 \mathrm{~K})$. The leaching activation energies presented in Table 2 are based on the Arrhenius plots of Figure 9. The lowest activation energy for leaching $(26.71 \mathrm{~kJ} / \mathrm{mol})$, as shown, correspond with the overall best calcine for the clay considering the aluminium solubility rate $(52.26 \%)$. Given that activation energy is the energy barrier that must be surmounted for a reaction to occur; the lowering of this energy means that leaching reaction is made thermodynamically or energetically easier, thus enhancing reaction rates or kinetics. This explains why clay calcine produced at $700{ }^{\circ} \mathrm{C}$ (holding for 60 minutes) yielded the highest solubility of alumina from the clay as shown by the \% $\mathrm{Al}$ in leach solution. It was also observed that the uncalcined sample of the clay required the highest activation energy of leaching $(35.07 \mathrm{~kJ} / \mathrm{mol})$; explaining why it was very difficult to leach alumina from such sample, as seen in its very low solubility data (\%Al taken into the leach solution). Thus, the alumina in uncalcined or unactivated clay is locked up in the clay chemistry, responding very sluggishly to acid attack. Similarly, clay sample calcined at $1000{ }^{\circ} \mathrm{C}$ for 60 minutes recorded the next highest activation energy $(33.24 \mathrm{~kJ} / \mathrm{mol})$ after the uncalcined clay. Leaching of alumina was also difficult in this case because at $1000{ }^{\circ} \mathrm{C}$, formation of crystalline phases had commenced. Thus, the alumina is again locked up in the mullite network, making it difficult for acid attack. Similar findings were reported in literature [37] [38] [39] [40]. As shown in Table 2 and Figure 10, values of activation energy varied between 
the extremes of the high values reported for the uncalcined clay at $\sim 25{ }^{\circ} \mathrm{C}$ and those for samples calcined at $1000{ }^{\circ} \mathrm{C}$; reaching the lowest value of $26.71 \mathrm{~kJ} / \mathrm{mol}$ at $700{ }^{\circ} \mathrm{C}$.

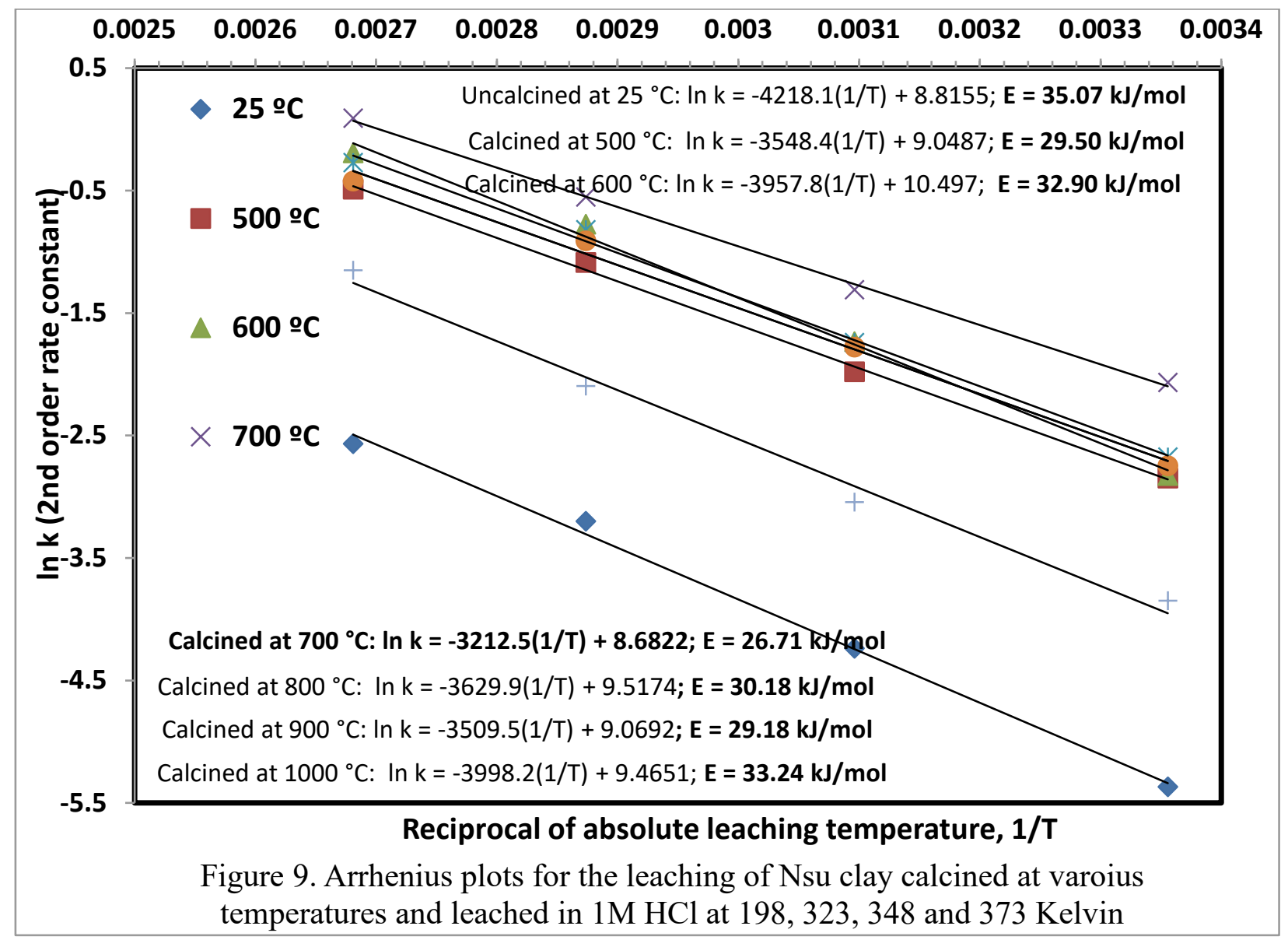

Table 2. Effect of calcination temperature (60 minutes holding time) on the leaching rate and activation energy

\begin{tabular}{|c|c|c|}
$\begin{array}{c}\text { Calcination } \\
\begin{array}{c}\text { Temperature } \\
\left({ }^{\circ} \mathbf{C}\right)\end{array}\end{array}$ & $\begin{array}{c}\text { Al extracted after } 1 \mathrm{hr} \text { of } \\
\text { leaching at } 100^{\circ} \mathrm{C} \\
(\%)\end{array}$ & $\begin{array}{c}\text { Activation Energy of } \\
\text { Leaching, } E_{a} \\
(\mathrm{~kJ} / \mathrm{mol})\end{array}$ \\
\hline 25 & 7.12 & 35.07 \\
\hline 500 & 38.00 & 29.50 \\
\hline 600 & 45.18 & 32.92 \\
\hline $\mathbf{7 0 0}$ & $\mathbf{5 2 . 2 6}$ & $\mathbf{2 6 . 7 1}$ \\
\hline 800 & 43.26 & 30.18 \\
\hline 900 & 39.60 & 29.18 \\
\hline 1000 & 24.02 & 33.24 \\
\hline
\end{tabular}




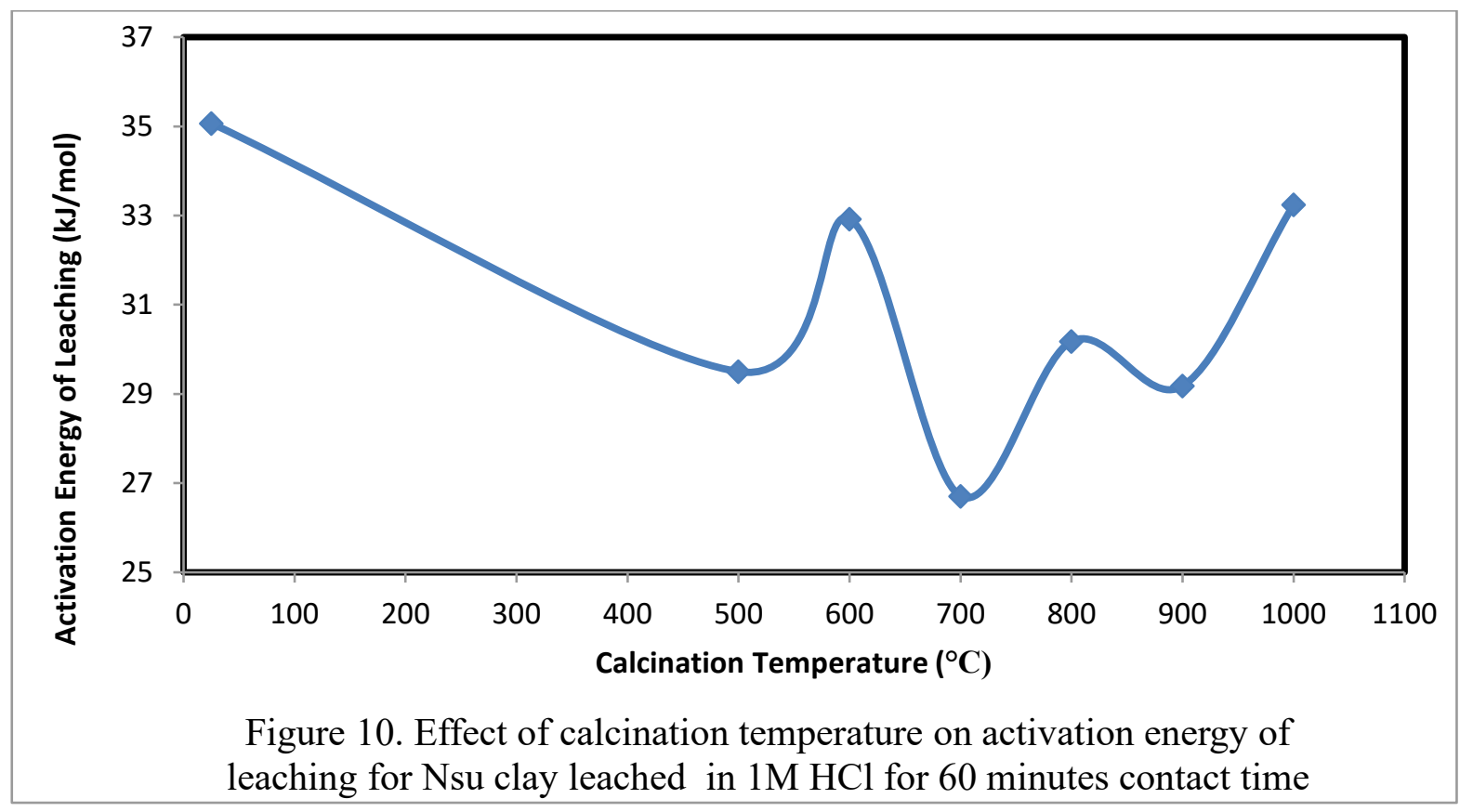

\section{Conclusions}

The thermal treatment conditions required for transforming Nsu clay to metakaolinite for enhanced leaching response was investigated. Different thermal treatments produced different degrees of leaching response from the clay based on the nature and degree of phase transformation. $\mathrm{X}$-ray diffraction studies confirmed that the highest dissolution rate of alumina corresponded with the thermal treatment that transformed the clay to an amorphous phase or metakaolinite. The clay was transformed from its low-temperature crystalline form to an amorphous form (at $700{ }^{\circ} \mathrm{C}$ ) and then back to high-temperature crystalline phases. Prolonged heating (above 90 minutes) under isothermal conditions also caused the appearance of crystalline phases and loss of solubility. Best results were achieved under 60 minutes heating duration at $700{ }^{\circ} \mathrm{C}$. Thermal treatment also affected the activation energy of leaching such that high solubility (high leaching response) corresponded with low activation energy. Thermally activated Nsu clay can be used as alternative resource for alumina in Nigeria where bauxite is scarce.

\section{Conflict of Interest}

The authors hereby declare that there is no conflict of interest whatsoever with the publication of this work

\section{Acknowledgments}

The authors are grateful to the Federal University of Technology, Owerri, a research fellowship (REG/EST/SPMU/SP.2318) that funded this work. The authors would also like to thank the unknown reviewers for their helpful comments and suggestions. 


\section{References}

[1] K. Hudson, C. Misra, K. Wefers. Aluminium oxide. In F. Habashi (Ed.), Handbook of extractive metallurgy, volume II, part 3: light metals (1997) pp.1062-1068. New York: John Wiley \& Sons, Inc.

[2] K. Hudson, C. Misra, K. Wefers. Bauxite, the principal alumina raw material. In F. Habashi (Ed.), Handbook of extractive metallurgy, volume II, part 3: light metals (1997) pp.1068-1072. New York: John Wiley \& Sons, Inc.

[3] K. Hudson, C. Misra, K. Wefers. Other processes for alumina production. In F. Habashi (Ed.), Handbook of extractive metallurgy, volume II, part 3: light metals (1997), pp.1091-1094. New York: John Wiley \& Sons, Inc.

[4] L.K. Hudson, C. Misra, A.J. Perrotta, K. Wefers, F.S.Williams. Aluminum oxide. In Barbara Elvers (Ed.), Ullman's encyclopedia of industrial chemistry, 7th ed. (2011), 40pp. Wiley-VCH, Weiheim.

[5] F. Habashi. Bayer's process for alumina production: a historical perspective. Bulletin of Historical Chemistry, Nos.17-18, (1995), pp.15-19.

[6] F. Habashi. A short history of hydrometallurgy. Hydrometallurgy, 79(1-2), (2005), 15-22. http://dx.doi.org/10.1016/j.hydromet.2004.01.008

[7] United States Geological Survey. Bauxite and alumina. In 2013 Minerals Yearbook (Advance Release). 13pp

[8] United States Geological Survey. Aluminium: mineral commodity summaries, 30 January 2015, pp.16-17. http://dx.doi.org/10.3133/70140094

[9] United States Geological Survey. Bauxite and alumina: mineral commodity summaries, 30 January 2015, pp.26-27. http://dx.doi.org/10.3133/70140094

[10] United States Geological Survey. Bauxite and alumina: mineral industry surveys, first quarter of 2015, pp.1-5.

[11] T. Schwarz. Distribution and genesis of bauxite on the Mambilla Plateau, SE Nigeria. Applied Geochemistry, 12(2), (1997), pp.119-131. http://dx.doi.org/10.1016/s0883-2927(96)00058-3

[12] S.W. Petters. Metallic and nonmetallic (industrial) minerals. In I.A. Adalemo \& J.M. Baba (Eds.), Nigeria: giant in the tropics, volume 1: a compendium (1993), p.61. Lagos: Gabuno Pub. Ltd.

[13] N.G. Obaje. Geology and mineral resources of Nigeria: lecture notes in earth sciences 120. Springer: London, (2009), pp.52, 118-119, 183-201.http://dx.doi.org/10.1007/978-3-54092685-6

[14] V.V. Pabalkar. Nigerian aluminium industry: scope and prospects. Proceedings of the 16th Annual Conference of the Nigerian Metallurgical Society (NMS), 3rd-5th November, 1999, Abuja, pp. 1-7

[15] J.B. Wright, D.A. Hastings, W.B. Jones, H.R. Williams. Geology and mineral resources of West Africa. London: George Allen \& Unwin (Publishers) Ltd, (1985), pp.35, 48-49, 87, 119, 145, 157. http://dx.doi.org/10.1007/978-94-015-3932-6

[16] B.A. Okorie. The metallurgical industry and national development. A Keynote Address Presented at the 2nd Annual NAMMES Conference Tagged 'FUTO 2000', 16th - 17th March, 2000. FUT, Owerri, 8pp

[17] S. Malomo Framework and opportunities for sustainable private sector participation in solid minerals development in Ekiti state; Ekiti State Economic Development Summit, 15 October., 2011

[18] A.O. Talabi, O.L. Ademilua, O.Z. Ajayi, S.O. Ogunniyi. Preliminary geophysical evaluation of Orin bauxite deposit, southwestern Nigeria. Journal of Emerging Trends in Engineering and Applied Sciences, 4(3), (2013), pp.432-437.

[19] M.M. Sada Mid-term report for the minerals and metals sector. Ministerial Platform Presented by Minister, Ministry of Mines and Steel Development (MMSD), June 2013.

[20] A. Aliyu. Potentials of the solid minerals industry in Nigeria. Abuja: RMRDC. (1996), pp. 140, 63-83, 164-172 
[21] G. Adeniji. An overview of Nigeria's solid minerals sector. ACCENTURE Knowledge Event, 19 January, 2009, pp.1-10.

[22] L.C. Fejokwu (ed.). Nigeria: a viable black power, volume 2: resources, potentials and challenges. Lagos: Polcom Press, (1996), pp.375-385

[23] Barsoum, M.W. Fundamentals of ceramics (second ed.). Bristle: IOP Publishing Ltd, (2003), pp.70-74

[24] J.F. Shackelford. Introduction to materials science for engineers (eighth ed.). Upper Saddle River, NJ: Pearson Higher Education, Inc., (2015), pp.71-72

[25] J.E. Prentice. Geology of construction materials: topics in the earth sciences 4; London: Chapman and Hall. (1990), pp.139-170.

[26] B. Velde. Composition and mineralogy of clay minerals. In B. Velde (Ed.), Origin and mineralogy of clays: clays and the environment, Verlag: Springer, (1995), pp.8-29.

[27] U. Mark, O.O. Onyemaobi. Assessment of the industrial potentials of some Nigerian kaolinitic clay deposits. International Research Journal in Engineering, Science \& Technology, 6(1), (2009), 77-84.

[28] A.K. Chakraborty. Phase transformations of kaolinite clay. New Delhi: Springer, (2014), pp.312, 43-47, 185-206, \& 327-329. http://dx.doi.org/10.1007/978-81-322-1154-9

[29] B. Velde. Introduction to clay minerals: chemistry, origins, uses and environmental significance. London: Chapman \& Hall, (1992), pp.1-17, 55-82, 96

[30] W.G. Fahrenholtz. Clays. In J.F. Shackelford \& R.H. Doremus (eds.), Ceramic and glass materials: structure, properties and processing. New York: Springer, (2008), pp.111-133

[31] Kaolinite. In Wikipedia. Last 273 modified on 1 December 2015, at 22:25; Accessed on 2 December 2015, at 6:44 Retrieved from https://en.wikipedia.org/w/index.php?title=Kaolinite\&oldid=693335566.

[32] D.J. Duval, S.H. Risbud, J.F. Shackelford, Mullite. In J.F. Shackelford \& R.H. Doremus (Eds.), Ceramic and glass materials: structure, properties and processing, New York: Springer, (2008), pp.27-39.

[33] A.A. Lamberov, E.Yu. Sitnikova, A.Sh. Abdulga, Kinetic features of phase transformation of kaolinite into metakaolinite for kaolin clays from different deposits. Russian Journal of Applied Chemistry, 85(6), (2012), 892-897. http://dx.doi.org/10.1134/s1070427212060109

[34] A. Ghosh, S. Ghosh. A Textbook of Metallurgical Kinetics. Delhi: PHI Learning Private Ltd. (2014), pp. 1-10, 82-100, 151-185, 301-319.

[35] C.K. Gupta. Chemical metallurgy: principles and practice. Weinheim: Wiley-VCH Verlag GmbH \& Co.(2003), pp.31-52, 459-499

[36] S.R.R. Rao. Hydrometallurgical processes. Published as Chapter 4 in Resource Recovery and Recycling from Metallurgical Wastes (Waste Management Series, Volume 7, (2006), pp.71108. Oxford, U.K.: Elsevier Sci. http://dx.doi.org/10.1016/s0713-2743(06)80089-9

[37] A.A. Al-Zahrani, M.H. Abdul-Majid, Extraction of alumina from local clays by hydrochloric acid process. Engineering Science Journal of King Abdulaziz University, Saudi Arabia, 20(2), (2009), 29-41. http://dx.doi.org/10.4197/eng.20-2.2

[38] A.W.A. Al-Ajeel, S.I. Al-Sindy. Alumina recovery from Iraqi kaolinitic clay by hydrochloric acid route. Iraqi Bulletin of Geology and Mining, 2(1), (2006), 67-76.

[39] R.O. Ajemba, O.D. Onukwuli. Determination of the optimum dissolution conditions of Ukpor clay in hydrochloric acid using response surface methodology. International Journal of Engineering Research and Applications, 2(5), (2012), 732-742.

[40] U. Udeigwe, O.D. Onukwuli, R. Ajemba, C.N. Ude. Kinetic studies of hydrochloric acid leaching of alumina from Agbaja clay. International Journal of Research in Advanced Engineering and Technology, 1(1), (2015), 64-72 